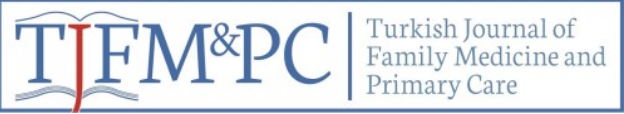

Original Research / Özgün Araştırma

\title{
The Relationship Between Participation in Mammography Screening Program and Health Literacy
}

\author{
Mamografi Tarama Programına Katılım ve Sağlık Okuryazarlığı Arasındaki İlişki \\ Osman Özkan Keskin ${ }^{*}$, Çiğdem Çă̆layan ${ }^{1}$
}

\begin{abstract}
Background/Aim: Breast cancer is the most common type of cancer in women around the world. This study aimed to determine the factors that affect participation in a mammography screening program, and analyze the effect of health literacy on women's level of participation in this program.Methods: The study was planned as a case-control study. Women aged 40-69 years were included in the study. The cases consisted of women who had never participated in the mammography screening program before, and controls consisted of women who had participated in the mammography screening program in the last two years. The study used Turkey Health Literacy Scale and a data form that included questions about participants' sociodemographic characteristics and reasons for not having participated in the screening program. The data were collected in a family health center and the Cancer Early Diagnosis Screening and Training Centers (CEDSTC) between April and June 2017 during individual interviews. Results/Findings: A total of 619 individuals (case group: 212; control group: 407) participated in this study. The scores of the women that had not participated in the mammography screening program on health literacy scale (29.2 \pm 6.8$)$ were lower than that of the women that had participated in this program $(33.7 \pm 4.8)(\mathrm{p}<0.05)$. In logistic regression analysis, having benign breast diseases (OR: 0.04$)$ and breast cancer history of their family (OR: 0.36 ) and friends (OR: 0.22 ) decrease the risk of avoiding mammography screening. This risk of not participating in screening was higher among the women that were working in jobs bringing income to them (OR: 1.74). In addition, the numerical variables, health literacy score (OR: 0.84), age (OR: 0.96) and number of children (OR: 0.62) increased, the risk of not participating in the screening program was found to decrease.Conclusion: Improving health literacy in women is a factor that positively affects participation in breast cancer screening program. It is also necessary to plan support for women in working life to increase participation in the screening programs.
\end{abstract}

Keywords: Mammography, Screening Program, Health Literacy

\section{ÖZET}

Giriş/Amaç: Meme kanseri, dünyada kadınlarda en sık görülen kanser türüdür. Bu çalışmada, kadınların ulusal meme kanseri tarama programına katılımını etkileyen faktörleri belirlemek ve sağlık okuryazarlığının katılım üzerindeki etkisini incelemek amaçlanmıştır. Yöntem: Çalışma, olgu kontrol çalışması olarak plandı. Çalışmaya, 40-69 yaş arasındaki kadınlar dahil edildi. Olgular daha önce tarama programına katılmamış kadınlardan, kontroller ise son iki yıl içerisinde meme kanseri tarama programına katılan kadınlardan oluşuyordu. Araştırmada, Türkiye Sağlık Okuryazarlığı Ölçeği ve katılımcıların sosyodemografik özellikleri ve tarama programına katılmama nedenleri hakkında sorular içeren bir veri formu kullanılmıştır. Veriler Nisan-Haziran 2017 ayları arasında bir aile sağlığı merkezi ve Kanser Erken Teşhis, Tarama ve Eğitim Merkezi (KETEM)'nde yüz yüze görüşme yöntemi ile toplanmıştır. Bulgular: Çalışmaya toplam 619 kişi (olgu grubu: 212; kontrol grubu: 407) katılmıştır. Sağlık okuryazarlığı ölçeğinde meme kanseri tarama programına katılmayan kadınların skoru $(29,2 \pm 6,8)$, tarama programa katılanların skorundan daha düşüktü $(33,7 \pm 4,8)(p<0,05)$. Lojistik regresyon analizinde, iyi huylu meme hastalıklarına sahip olma (OR: 0.04), ailede (OR: 0.36) veya arkadaşları arasında meme kanserinin görülmesi (OR: 0.22) durumunda meme kanseri taramasına katılmama riskinin azaldığı saptandı. Bu risk, gelir getirici işlerde çalışan kadınlarda yüksek saptandı (OR: 1.74). Ek olarak, numerik değişkenler olan sağlık okuryazarlığı skoru (OR: 0.84), yaş (OR: 0.96) ve çocuk sayısının artışı (OR: 0.62), tarama programına katılmama riskini azalttı̆̆ saptandı. Sonuç: Kadınlarda sağlık okuryazarlığının geliştirilmesi meme kanseri tarama programı katılımına olumlu etki yapan bir faktördür. Ayrıca tarama programına katılımı artırmak için çalışma hayatındaki kadınlara yönelik desteklerin planlanması gereklidir.

Anahtar Kelimeler: Mamografi, Tarama Programı, Sağlık Okuryazarlı̆̆ı

Received date / Geliş tarihi: 29.02.2016, Accepted date / Kabul tarihi: 12.03.2016

${ }^{1}$ Kocaeli University Medicine Faculty Public Health Department, Kocaeli, TURKEY.

*Address for Correspondence / Yazışma Adresi: Osman Özkan Keskin, Kocaeli University Medicine Faculty Public Health Department,Kocaeli,TURKEY.

E-mail: osmankeskin28@hotmail.com

Keskin O, Caglayan C. The Relationship Between Participation in Mammography Screening Program and Health Literacy. TJFMPC, 2019;13(4): 448-456.

DOI: $10.21763 /$ tjfmpc.651461 


\section{INTRODUCTION}

Breast cancer is the most common cancer type in women around the world regardless of countries' development levels. ${ }^{1}$ Similarly, one out of every 4 cancer-diagnosed women in Turkey has breast cancer. ${ }^{2}$ Each year, approximately 1.7 million breast cancer cases are reported around the world. The incidence of breast cancer keeps increasing in developing countries due to prolonged lifespan, increased urbanization, and adoption of the western lifestyle. $^{3}$ The World Health Organization (WHO) encourages a comprehensive breast cancer control that includes prevention, early diagnosis, treatment, rehabilitation and palliative care in the context of cancer control programs. ${ }^{4}$

Breast self-examination (BSE), clinical breast examination and mammography screening are used for an early diagnosis of breast cancer. ${ }^{5}$ Mammography screening is the most effective method that can be used to diagnose breast cancer at early stage usually before any symptom is described by physical examination. ${ }^{5,6}$ Mammography screening programs have been used for 30 years or longer in developed countries. ${ }^{7}$ In Turkey, national standards for breast cancer screening were published in 2004 for the first time. Within the scope of the National Breast Cancer Screening Program, women aged between 40 and 69 years are given the opportunity to go through a free mammography every two years at the Cancer Early Diagnosis Screening and Training Centers (CEDSTCs). ${ }^{8}$

Studies conducted in different countries found that participation in mammography screening was affected by variables such as sociodemographic characteristics, personal experiences and health literacy. These studies also found that women who were married, had a history of breast cancer, and had adequate health literacy were more likely to participate in screenings than women who were not married and did not have a history of breast cancer and did not have adequate health literacy.9,10,11 Therefore, determining the factors that affect participation in mammography screening can create a basis to develop strategies to encourage participation. Health literacy is one of the key determinants of health. ${ }^{12}$ Adequate health literacy is described as the knowledge and the motivation that will help individuals to access, understand, assess, and use the knowledge about health. ${ }^{13}$ Inadequate health literacy is associated with more risky health preferences (e.g., smoking), the management of chronic diseases (e.g., diabetes, hypertension, asthma and HIV / AIDS), more frequent work accidents, increased morbidity, and premature death. ${ }^{14,15,16,17}$ Studies of the use of protective services have shown that people with inadequate health literacy use protective health services such as breast cancer screening less frequently ${ }^{10,18,19,20}$.

This study aims to identify the factors affecting participation in the National Mammography Screening Program conducted by CEDSTCs and to analyze the effect of health literacy on participation in this program.

\section{METHODS}

\subsection{The Design and Sample of the Study}

The population of the study consisted of women that were aged between 40 and 69 years, and were included in CEDSTC screening program. This is a case-control study. Since it is a negative situation not to participate in screening, the women who had not undergone mammography before were included in the case group, and the women who had mammography in CEDSTC in the past two years were included in the control group.

With the purpose of determining the effect of health literacy on mammography screening participation, the sufficient sample size was calculated based on the power and sample size formula is unmatched case-control studies. ${ }^{21} \mathrm{~A}$ Turkish study that was conducted in 2014 demonstrated that $64.6 \%$ of the population had limited health literacy. ${ }^{22}$ In a way to ensure that the ratio of the control group to the case group would be 2 , limited health literacy exposure was accepted to be $65 \%$ and the Odds Ratio (OR) related to exposure was accepted to be 2 within a confidence interval of $95 \%$ and a power of $90 \%$. Accordingly, the study planned to have at least 176 persons in the case group and at least 351 persons in the control group. A total of 619 patients participated in this study: 212 females were in the case group, and 407 females were in the control group.

The inclusion criteria for case group were being aged between 40 and 69 years, having no breast cancer diagnosis, declaring having never had mammography before, being literate and agreeing to participate in the study.

The inclusion criteria for the control group were being aged between 40 and 69 years, 
having no breast cancer diagnosis, having had mammography screening in CEDSTC in the last two years, being literate and agreeing to participate in the study.

\subsection{Variables and Data Collection Tool}

The dependent variable of the study was participation in the mammography screening program, and the main independent variable of the study was health literacy. The other independent variables are as follows: 1) sociodemographic characteristics (age, marriage, having children and the number of children, education level, residence, employment status, income level, social security, 2) benign breast symptoms or disease, 3 ) breast cancer history in family or friends, 4) breast self-examination, 5) mammography recommendation, and 6) the reasons for not participating in screening.

For the assessment of health literacy, the study used Turkey Health Literacy Scale-32 (THLS32) that was adapted from the European Health Literacy Scale and consisted of 32 Likert-type questions. General health literacy was grouped as "insufficient / problematic / sufficient / excellent" based on the scores obtained on the scale. The "insufficient" and "problematic" groups together formed the "limited" group. The reliability and validity study of the scale was performed on literate people (Cronbach's Alpha: 0.927). In addition to the health literacy scale, the study used the data collection form that was created by the researchers.

\subsection{Data Collection}

The researchers selected a family health center in İzmit city center and the CEDSTC where the mammography screening was performed to contact the women in case and control groups. The distance between two centers was approximately 250 meters. The data were collected between April and June 2017. The women that met the inclusion criteria were informed about the survey. Then, the data were collected by the researcher during individuals interviews with women who agreed to participate in the survey using the survey form.

\subsection{Approvals}

Ethical approval required for the study was obtained from Kocaeli University's Ethical Committee. Also, administrative approval was obtained from Kocaeli Public Health Directorship.

\subsection{Statistical Analysis}

All statistical analyses were performed using SPSS version 20.0 (SPSS Inc, Chicago, IL, USA). Mann-Whitney $U$ test was used to determine the relationship between the dependent variable and age, number of children, and the score on health literacy since the variables did not have a normal distribution. The chi-square test was used for categorical data, and ORs were calculated with a confidence interval. Variables with a p-value of $<0.05$ on univariate analysis were included in the model for multivariate analysis, and a multiple binary logistic regression analysis was conducted with them. Multiple logistic regression was conducted using backward elimination method to assess the predictors of participation. The significance level was accepted to be $\mathrm{p}<0.05$ for all analyses.

\section{Results/Findings}

A total of 619 participants (212 females in the case group and 407 females in the control group) participated in this study. The mean age of the case group was $47.6 \pm 8.5$ years, and that of the control group was $50.8 \pm 7.3$ years. The mean number of children was $2.1 \pm 1.2$ in the case group, and $2.5 \pm 1.2$ in the control group. The mean age and number of children were lower in the case group than in the control group $(\mathrm{p}<0.05)$. Categorical variables which may affect mammography screening program are presented in Table 1 . 


\begin{tabular}{|c|c|c|c|c|c|c|}
\hline & & \multicolumn{2}{|c|}{ Cases } & \multicolumn{2}{|c|}{ Controls } & \multirow{2}{*}{$\begin{array}{l}\text { Crude OR } \\
(95 \% \mathrm{CI})\end{array}$} \\
\hline & & $\mathbf{n}$ & $\%$ & $\mathbf{n}$ & $\%$ & \\
\hline \multirow[t]{2}{*}{ Marital Status } & Married & 190 & 89.6 & 378 & 92.9 & \multirow{2}{*}{$\begin{array}{l}0.66 \\
(0.37-1.18)\end{array}$} \\
\hline & Not married & 22 & 10.4 & 29 & 7.1 & \\
\hline \multirow[t]{2}{*}{ Children } & Yes & 187 & 88.2 & 377 & 92.6 & \multirow{2}{*}{$\begin{array}{l}0.59 \\
(0.34-1.04)\end{array}$} \\
\hline & No & 25 & 11.8 & 30 & 7.4 & \\
\hline \multirow[t]{2}{*}{ Educational Level } & $\begin{array}{l}\text { Illiterate/Primary } \\
\text { school graduate }\end{array}$ & 81 & 38.2 & 189 & 46.4 & \multirow[t]{2}{*}{$\begin{array}{l}0.71 \\
(0.51-1.00)\end{array}$} \\
\hline & Higher education & 131 & 61.8 & 218 & 53.6 & \\
\hline \multirow[t]{2}{*}{ Social Security } & Yes & 206 & 97.2 & 402 & 98.8 & \multirow{2}{*}{$\begin{array}{l}2.34 \\
(0.71-7.76)\end{array}$} \\
\hline & No & 6 & 2.8 & 5 & 1.2 & \\
\hline \multirow[t]{2}{*}{ Working Status } & Yes & 66 & 31.1 & 88 & 21.6 & \multirow{2}{*}{$\begin{array}{l}1.64 * * \\
(1.13-2.38)\end{array}$} \\
\hline & No & 146 & 68.9 & 319 & 78.4 & \\
\hline \multirow[t]{2}{*}{ Income level } & Less than income & 75 & 35.4 & 115 & 28.3 & \multirow{2}{*}{$\begin{array}{l}1.39 \\
(0.97-1.98)\end{array}$} \\
\hline & Equal/More & 137 & 64.6 & 292 & 71.7 & \\
\hline \multirow[t]{2}{*}{ Residence } & Province/County & 210 & 99.1 & 395 & 97.1 & \multirow{2}{*}{$\begin{array}{l}3.19 \\
(0.71-14.39\end{array}$} \\
\hline & Town/Village & 2 & 0.9 & 12 & 2.9 & \\
\hline \multirow{2}{*}{$\begin{array}{l}\text { Benign Breast } \\
\text { Symptoms }\end{array}$} & Yes & 23 & 10.8 & 36 & 8.8 & \multirow{2}{*}{$\begin{array}{l}1.25 \\
(0.72-2.18)\end{array}$} \\
\hline & No & 189 & 89.2 & 371 & 91.2 & \\
\hline \multirow{2}{*}{$\begin{array}{l}\text { Benign Breast } \\
\text { Disease }\end{array}$} & Yes & 1 & 0.5 & 74 & 18.2 & \multirow{2}{*}{$\begin{array}{l}0.02 * * \\
(0.00-0.15)\end{array}$} \\
\hline & No & 211 & 99.5 & 333 & 81.8 & \\
\hline \multirow{2}{*}{$\begin{array}{l}\text { Breast Cancer } \\
\text { History in Family }\end{array}$} & Yes & 15 & 7.1 & 89 & 21.9 & \multirow{2}{*}{$\begin{array}{l}0.27 * * \\
(0.15-0.48)\end{array}$} \\
\hline & No & 197 & 92.9 & 318 & 78.1 & \\
\hline \multirow{2}{*}{$\begin{array}{l}\text { Breast Cancer } \\
\text { History in Friends }\end{array}$} & Yes & 27 & 12.7 & 163 & 40.0 & \multirow{2}{*}{$\begin{array}{l}0.22 * * \\
(0.14-0.34)\end{array}$} \\
\hline & No & 185 & 87.3 & 244 & 60.0 & \\
\hline \multirow[t]{2}{*}{ Knowledge of BSE } & Yes & 140 & 66.0 & 309 & 75.9 & \multirow{2}{*}{$\begin{array}{l}0.62 * * \\
(0.43-0.88)\end{array}$} \\
\hline & No & 72 & 34.0 & 98 & 24.1 & \\
\hline \multirow[t]{2}{*}{ Doing regular BSE } & Yes & 38 & 17.9 & 73 & 17.9 & \multirow{2}{*}{$\begin{array}{l}0.99 \\
(0.65-1.54)\end{array}$} \\
\hline & No & 174 & 82.1 & 334 & 82.1 & \\
\hline \multirow{2}{*}{$\begin{array}{l}\text { Mammography } \\
\text { Recommendation }\end{array}$} & Yes & 139 & 65.6 & 277 & 68.1 & \multirow{2}{*}{$\begin{array}{l}0.89 \\
(0.63-1.27)\end{array}$} \\
\hline & No & 73 & 34.4 & 130 & 31.9 & \\
\hline
\end{tabular}

*Chi-Square Test ${ }^{* *}$ Statistical significance: $p<0.05$

Of the women in the case group (the ones who did not participate in the mammography screening program), $89.6 \%$ were married and $88.2 \%$ had children while $61.8 \%$ graduated from high school or had a higher degree. There was no statistically significant difference between the case and control groups $(\mathrm{p}>0.05)$. Of the women in the control group (the ones who participated in the mammography program), however, $18.2 \%$ had a benign breast disease and $21.9 \%$ had a history of breast cancer in their family while $40 \%$ had a friend with breast cancer. The score of the women who participated in screening was significantly higher than that of those who did not $(\mathrm{p}<0.05)$. BSE knowledge had a statistically significant difference between the participants in case and control groups, and the women who underwent mammography were better informed about BSE $(75.9 \%$ and $66.0 \%$ for the women that did and did not participate in mammography, respectively) $(\mathrm{p}<0.05)$. Moreover, the rate of 
working women was significantly higher among the women that did not participate in screening than those who did $(31.1 \%$ and $21.6 \%)(\mathrm{p}<0.05)$.
Health literacy levels of case and control groups based on the score obtained from THLS-32 scale are shown in Table 2.

\begin{tabular}{|l|l|l|l|l|l|l|}
\hline Table 2. Participant Women's Health Literacy Level \\
\hline Health Literacy & Cases & Controls & p & $\begin{array}{l}\text { Crude OR } \\
\text { (95\%CI) }\end{array}$ \\
\cline { 2 - 7 } & n & $\%$ & n & \% & & \\
\hline Insufficient Problematic & 59 & 27.8 & 8 & 2.0 & & \\
Sufficient & 80 & 37.7 & 183 & 45.9 & $0.000^{*}$ & \\
Excellent & 71 & 33.5 & 194 & 47.7 & & \\
& 2 & 0.9 & 22 & 5.4 & & \\
\hline Limited & 139 & 65.5 & 191 & 47.9 & $0.000^{*}$ & 2.15 \\
(Insufficient+Problematic) & \multicolumn{7}{|l|}{} & & & & $(1.53-3.04)$ \\
\hline Score (Mean \pm SD) & $29.2 \pm 6.8$ & $33.7 \pm 4.8$ & $0.000^{* *}$ & \\
\hline
\end{tabular}

*Chi-Square Test **Mann-Whitney $U$

The Health Literacy Scale score of the women who had participated in the mammography screening program was higher than those who had never participated in it $(p<0.05)$. A categorical analysis of the scores showed that limited health literacy was 2.15 times higher in the individuals that had never participated in mammography program than those who did.
Variables that were statistically significant in univariate analysis and had an estimated effect on screening program participation was included in the model to perform logistic regression analysis, and the analysis results are shown in Table 3.

\begin{tabular}{|c|c|c|c|c|}
\hline & & $\begin{array}{l}\text { Cases (Non-attenders) } \\
\text { n (\%) }\end{array}$ & $\begin{array}{l}\text { Controls (Attenders) } n \\
(\%)\end{array}$ & OR (95\% CI) \\
\hline \multirow{2}{*}{ Working Status } & Yes & $66(31.1)$ & $88(21.6)$ & $1.74(1.05-2.88)^{*}$ \\
\hline & No & $131(61.8)$ & $218(53.6)$ & 1.000 \\
\hline \multirow{2}{*}{$\begin{array}{l}\text { Benign Breast } \\
\text { Disease }\end{array}$} & Yes & $1(0.5)$ & $74(18.2)$ & $0.04(0.01-0.32)^{*}$ \\
\hline & No & $211(99.5)$ & $333(81.8)$ & 1.000 \\
\hline \multirow{2}{*}{$\begin{array}{l}\text { Breast Cancer } \\
\text { History in Family }\end{array}$} & Yes & $15(7.1)$ & $89(21.9)$ & $0.36(0.18-0.69)^{*}$ \\
\hline & No & $197(92.9)$ & $318(78.1)$ & 1.000 \\
\hline \multirow{2}{*}{$\begin{array}{l}\text { Breast Cancer } \\
\text { History in Friends }\end{array}$} & Yes & $27(12.7)$ & $163(40.0)$ & $0.22(0.13-0.37)^{*}$ \\
\hline & No & $185(87.3)$ & $244(60.0)$ & 1.000 \\
\hline \multirow{3}{*}{ BSE Knowledge } & Yes & $140(66.0)$ & $309(75.9)$ & $0.67(0.42-1.06)$ \\
\hline & No & $72(34.0)$ & $98(24.1)$ & 1.000 \\
\hline & & Mean \pm Sd & Mean \pm Sd & \\
\hline Age (years) & & $47.6 \pm 8.5$ & $50.8 \pm 7.3$ & $0.96(0.93-0.99)^{*}$ \\
\hline Number of children & & $2.1 \pm 1.2$ & $2.5 \pm 1.2$ & $0.62(0.51-0.75)^{*}$ \\
\hline $\begin{array}{l}\text { Health Literacy } \\
\text { Score }\end{array}$ & & $29.2 \pm 6.8$ & $33.7 \pm 4.8$ & $0.84(0.80-0.88)^{*}$ \\
\hline
\end{tabular}

The results of logistic regression analysis in Table 3 show that the risk of not participating in mammography screening was reduced by having a history of breast cancer in family (OR: 0.36 ) or in friends (OR: 0.22 ) or having benign breast disease (OR: 0.04$)$. The risk of not participating in mammography screening was increased by being employed (OR: 1.74).
Health literacy score (OR: 0.84), age (OR: 0.96 ) and the number of children (OR: 0.62), which are all numerical variables, decreased the risk of not participating in screening program.

The reasons that women in the case group did not participate in the screening program are presented in Table 4. 


\begin{tabular}{|l|l|l|}
\hline Table 4. The reasons for not participating in screening program \\
\hline & n & $\%$ \\
\hline Having No Breast Symptom/Disease & 120 & 56.8 \\
\hline No time & 100 & 47.2 \\
\hline Not caring & 96 & 45.3 \\
\hline Not knowing that mammography is necessary & 22 & 10.4 \\
\hline A painful procedure & 21 & 9.9 \\
\hline Fear of cancer & 17 & 8.0 \\
\hline Worried that mammography can be harmful & 15 & 7.1 \\
\hline Belief that one is too young for it & 8 & 3.8 \\
\hline
\end{tabular}

* More than one is chosen

The most common reasons stated by the participants were having no breast symptoms/not having the disease (56.8\%), being unable to find time $(47.2 \%)$ and not caring about this issue $(45.3 \%)$.

\section{DISCUSSION}

A review of the relevant literature indicated that this is the first Turkish study that examines the relationship between communitybased cancer screening program participation and health literacy in Turkey. The strengths of the study were collecting data during individual interviews, the questions being asked to 619 women, and exceeding the target number in both groups. Case and control groups were not matched based on age, and the women who were aged between 40 and 69 years were included in the study. The aim of the researcher was to ensure similarity in education level, and it was observed that the women with similar literacy levels had distinctive levels in health literacy. However, it is probable that more disadvantaged slices of the society were neglected in the study due to the fact that case and control groups consisted of individuals that went to a health institution, and that both groups had the condition of being literate to fill out the health literacy scale.

It is important to understand potential benefits, harms, alternatives, and uncertainties of being a subject in this practice when deciding to participate in a screening program. To this end, health literacy of individuals plays a major role in health decisions. Our study showed that adequate health literacy is a variable that increases participation in screenings. In literature, similar results are found by previous studies that examined this relationship. A study conducted with people from Hispanic origin on the relationship between undergoing mammography and health literacy found that inadequate health literacy was related to fewer mammography screenings. ${ }^{10}$ A study by Fernandez et al. found that the probability of having had mammography in the last two years was higher of the women with adequate health literacy. ${ }^{23}$ A study conducted with women who came to a breast clinic and were over 40 years old found that limited health literacy was related to avoiding a screening. ${ }^{24} \mathrm{~A}$ study by Scot et al. conducted with people who were registered in Medicare and a study by Guerra et al. conducted with people from Latin origin both found that individuals with inadequate health literacy were at a greater risk of not having a mammography. ${ }^{25,19}$

Breast symptoms and diagnosed benign breast disease may affect women's motivation to use services for their problems. According to Andersen, this variable which is called a "perceived necessity" affects service users directly. ${ }^{26}$ Our study found that having benign breast disease encouraged individuals to participate in screenings. Similarly, personal breast disease history was related to participation in screenings in a study by Luengo et al. ${ }^{27} \mathrm{~A}$ study by Lagerlund et al. found that the probability of not participating screening was three times higher in women who did not have breast problems than those who had breast problems. ${ }^{9}$

Women who have breast cancer in their family or encounter these problems in their social circle may tend to participate in this program more as a result of higher awareness. Our study showed that having family members and friends who have been diagnosed with breast cancer increased participation in screenings. Similarly, a history of breast cancer in the family was related to participation in mammography screening in other studies as well. ${ }^{28,29}$

Being employed brings the advantage of being an individual that is open to social interactions, but it may also create a disadvantage of using one's own spare time, such as participating in mammography 
screening. There are several studies in the relevant literature showing that being employed makes a positive effect on participation in screenings. ${ }^{9,30,28}$ On the other hand, our study found that working women's rate of participation in mammography screening was lower. Approximately half of the women who did not participate in screening stated as a reason that they could not find time, which was a supportive finding for the result of our study.

In our study, aging and having more children were variables found to increase participation in the screening program. Participation may be affected by the following reasons: the number of younger women in professional life is higher than that of the older women, therefore they cannot find time or they perceive low risk; women with many children contact family doctors more than other women due to child monitoring. A study assessing community-based mammography screening participation by McNoe et al. found that age was not a factor in determining the difference between the women who did and did not participate in screening. ${ }^{31}$ A study by Lagerlund et al. found a positive relationship between participation in screening and not having any children or having five or more children. ${ }^{9}$

This study also questioned the reasons for not participating in screening of the women who had not participated in screening program with the purpose of determining women's perceptions of barriers before the service as well as the points that need to be intervened. The three common reasons stated by women for not participating in mammography screening program were not having a breast problem $(56.8 \%)$, not having time $(47.2 \%)$ and not caring about this issue $(45.3 \%)$. Similar findings were found in previous studies, too. The most frequent reason stated by women in the study by Yildirım et al. was not knowing that mammography was necessary $(43.6 \%) .^{32}$ A study by Leong et al. performed in

\section{REFERENCES:}

1. Coughlin SS, Ekwueme DU. Breast cancer as a global health concern. Cancer epidemiol 2009; 33(5): 315318.

2. T.C. Sağlık Bakanlığı Halk Sağlığ1 Kurumu. Türkiye Kanser İstatistikleri. Ankara, 2017. p.19-20. Web: https:/hsgm.saglik.gov.tr/depo/biriml er/kanser-db/istatistik/2014-
Singapore found that not having enough time $(42.5 \%)$ and not believing in having cancer $(24.6 \%)$ were the two most commonly observed reasons for not participating in the program. $^{33}$

\section{CONCLUSIONS}

In our study, it was found that limited health literacy was higher in the group that had never participated in a screening program, and participation in screenings increased in direct proportion with health literacy. Our recommendations deduced from our findings were as follows:

- Women's health literacy should be improved. Strong policies should be developed and implemented by addressing this subject.

- Certain measures should be considered addressing to working class for enabling them to use screening services during working hours. Workplace health and safety units have key roles in this subject.

- Women who have benign breast disease and have people diagnosed with breast cancer in their family or social environment used screening services more. The screening services are mainly addressed to healthy women. Therefore, family physicians should provide counseling to each woman in the risk group and direct them to CEDSTCs.

- Researchers and authorities should access young women, and have them use the opportunities they missed before.

- Public awareness about breast cancer should be increased considering the reasons that women did not participate in the screening program.

- Our study was conducted with a population of individuals that are at risk. It is also necessary to conduct studies on organization and resource dimensions of the health system which affect the participation in breast cancer screening programs.
RAPOR._uzuuun.pdf Accessed 14.06.19

3. Ferlay J, Héry C, Autier P, Sankaranarayanan R. Global burden of breast cancer. In: $\mathrm{Li} \mathrm{C}$ editor. Breast cancer epidemiology. Springer New York, 2010. p.1-19. 
4. World Health Organization. Breast cancer: prevention and control. Web: http://www.who.int/cancer/detection/ breastcancer/en/.

Accessed 10.10.2017

5. Rogers C. IARC Handbooks of Cancer Prevention, Volume 7: Breast Cancer Screening.Lyon, France: 1ARCPress; 2002. p.171-185.

6. Sankaranarayanan R, Ramadas K, Thara S, Muwonge R, Prabhakar J,Augustine $\mathrm{P}$ et al. Clinical breast examination: preliminary results from a randomized controlled trial in India. Jnci-J Natl Cancer I 2011;103:14761480.

7. Shapiro S, Coleman EA, Broeders M, Codd M, de Koning H, Fracheboud J et al. Breast cancer screening programmes in 22 countries: current policies, administration and guidelines: Int J Epidemiol 1998; 27(5): 735-742.

8. Kanser Daire Başkanlığı. Meme Kanseri Tarama Programı Ulusal Standartlar1. p.41. Web: https:/hsgm.saglik.gov.tr/depo/biriml er/kanserdb/yayinlar/raporlar/Ulusal_Kanser_ Kontrol_Plani_2013_2018.pdf. Accessed 14.06.19

9. Lagerlund M, Maxwell AE, Bastani R, Thurfjell E, Ekbom A, Lambe M. Sociodemographic predictors of nonattendance at invitational mammography screening-a population-based register study (Sweden). Cancer Cause Control 2002; 13(1): 73-82.

10. Pagán JA, Brown CJ, Asch DA, Armstrong K, Bastida E, Guerra C. Health literacy and breast cancer screening among Mexican American women in South Texas. J Cancer Educ 2012; 27(1): 132-137.

11. Bare ML, Montes J, Florensa R, Sentis M, Donoso L. Factors related to non-participation in a populationbased breast cancer screening programme. Eur J Cancer Prev 2003; 12(6): 487-494.

12. Kickbusch I, Pelikan MJ, Apfel P, Tsouros AD (ed). Health literacy: the solid facts. Geneva: World Health Organization, 2013. p.7-11. Web: http://www.euro.who.int/_data/asset s/pdf_file/0008/190655/e96854.pdf

Accessed 14.06.19

13. Sorensen K, Van den Broucke S, Fullam J, Doyle G, Pelikan J, Slonska $\mathrm{Z}$ et al. Health literacy and public health: a systematic review and integration of definitions and models. BMC public health 2012; 12(1): 80.

14. Berkman ND, Sheridan SL, Donahue KE, Halpern DJ, Crotty K. Low health literacy and health outcomes: an updated systematic review. Ann Intern Med 2011; 155(2): 97-107.

15. Waldrop-Valverde D, Jones DL, Jayaweera D, Gonzalez P, Romero J, Ownby RL. Gender differences in medication management capacity in HIV infection: The role of health literacy and numeracy. AIDS Behav 2009; 13(1): 46-52.

16. Estrada CA, Martin-Hryniewicz M, Peek BT, Collins C, Byrd JC. Literacy and numeracy skills and anticoagulation control. Am J Med Sci 2004; 328(2): 88-93.

17. Davis TC, Wolf MS, Bass PF, Middlebrooks M, Kennen E, Baker DW et al. Low literacy impairs comprehension of prescription drug warning labels. J Gen Intern Med 2006; 21(8): 847-851.

18. White S, Chen J, Atchison R. Relationship of preventive health practices and health literacy: a national study. Am J Health Behav 2008; 32(3): 227-242.

19. Guerra CE, Krumholz M, Shea JA. Literacy and knowledge, attitudes and behavior about mammography in Latinas. J Health Care Poor U 2005; 16(1): 152-166.

20. Cho YI, Lee SY, Arozullah AM, Crittenden KS. Effects of health literacy on health status and health service utilization amongst the elderly. Soc Sci Med 2008; 66(8): 1809-1816.

21. Schlesselman JJ. Case-control studies: design, conduct, analysis. Oxford University Press.1982. p.145

22. Durusu-Tanrı̈̈ver M, Yıldırım HH, Demiray-Ready FN, Çakır B ve Akalın HE, editors. Türkiye Sağlık Okuryazarlığı Araştırması. 1. Baskı. 
Ankara: Sağlık-Sen Yayınları, Aralık 2014. p.55.

23. Fernandez DM, Larson JL, ZikmundFisher BJ. Associations between health literacy and preventive health behaviors among older adults: findings from the health and retirement study. BMC public health 2016; 16(1): 596-603.

24. Komenaka IK, Nodora JN, Hsu CH, Martinez ME, Gandhi SG, Bouton $\mathrm{ME}$ et al. Association of health literacy with adherence to screening mammography guidelines. Obstet Gynecol 2015; 125(4): 852-859.

25. Scott TL, Gazmararian JA, Williams MV, Baker DW. Health literacy and preventive health care use among Medicare enrollees in a managed care organization. Med Care 2002; 40(5): 395-404.

26. Andersen R. Revisiting the behavioral model and access to medical care:Does it matter? J Health Soc Behav 1995; 36(1): 1-10.

27. Luengo S, Lazaro P, Azcona B, Madero R, Fitch K. Use of mammography among women residing in Spanish provinces with breast cancer screening programmes. Eur J Cancer Prev 1999; 8(6): 517 524.
28. Duport N, Ancelle-Park R. Do sociodemographic factors influence mammography use of French women? Analysis of a French crosssectional survey. Eur J Cancer Prev 2006; 15(3): 219-224.

29. Rahman SM, Dignan MB, Shelton BJ. Factors influencing adherence to guidelines for screening mammography among women aged 40 years and older. Ethn Dis. 2003; 13(4): 477-484.

30. Aro AR, De Koning HJ, Absetz P, Schreck M. Psychosocial predictors of first attendance for organised mammography screening. J Med Screen 1999; 6(2): 82-88.

31. McNoe B, Richardson AK, Elwood JM. Factors affecting participation in mammography screening. New Zeal Med J 1996; 109: 359-361.

32. Yıldırım DA, Özaydın NA. Sources of breast cancer knowledge of women living in Moda/İstanbul and their attendance to breast cancer screening. J Breast Health 2014; 10: 47-56.

33. Leong HS, Heng R, Emmanuel SC. Survey on mammographic screening among women aged 40 to 65 years old at polyclinics. Singapore Med J 2007; 48: 34-40. 